\title{
KARAKTERISASI UNAGI SHIRAYAKI BERBAHAN IKAN SIDAT DENGAN PERENDAMAN ENZIM PAPAIN
}

\author{
Emma Rochima*1; Windi Damayanti ${ }^{1}$ \\ 1 Departemen Perikanan, Fakultas Perikanan dan IImu Kelautan, Universitas Padjadjaran \\ Jl. Raya Bandung - Sumedang Km 21, Jatinangor 45363, Jawa Barat, Indonesia \\ *Korespondensi: emma.rochima@unpad.ac.id \\ (Diterima 02-06-2020; Direvisi 08-06-2020; Dipublikasi 18-06-2020)
}

\begin{abstract}
ABSTRAK
Unagi Shirayaki bahan antara yang digunakan sebagai bahan pembuatan Unagi Kabayaki. Shirayaki yang diolah dan ditambahkan saus khusus menghasilkan produk olahan dengan teksur yang lembut dan empuk. Kendala yang dihadapi dalam mengolah unagi kabayaki adalah munculnya tekstur daging sidat yang alot berasal dari sidat abnormal (brown) yang berbeda dari sidat normal (black) yang dapat mengakibatkan penurunan tingkat kesukaan konsumen. Salah satu upaya dalam perbaikan tekstur unagi adalah dengan perendaman menggunakan enzim papain. Tujuan penelitian ini untuk mengetahui karakteristik Unagi Shirayaki hasil perendaman enzim serta untuk mengetahui konsentrasi dan lama perendaman terbaik untuk memperbaiki karakteristik Unagi Shirayaki. Sebanyak 3 perlakuan konsentrasi enzim papain (0,5, 1,0 dan 1,5\%) dan 3 lama perendaman $(5,10,15$ menit) digunakan dalam penelitian ini. Parameter yang diuji meliputi kadar proksimat (kadar air, kadar abu, kadar lemak, kadar protein), total bakteri, pH, tekstur dan organoleptik. Hasil penelitian menunjukan bahwa konsentrasi dan lama perendaman enzim papain terbaik untuk memperbaiki karakteristik Unagi Shirayaki adalah perendaman menggunakan larutan enzim papain dengan konsentrasi sebesar $0.5 \%$ selama 15 menit. Produk yang dihasilkan memiliki total koloni bakteri $1,04 \times 10^{-3}, \mathrm{pH} \mathrm{7,0}$, kadar air sebesar $51,39 \%$, kadar lemak $18,24 \%$, kadar protein $26,70 \%$ kadar abu $0,85 \%$, kadar gula reduksi $0,00 \%$, tingkat kekerasan $2,493.11 \mathrm{~g} /$ Force, kekenyalan $57,85 \mathrm{~g} /$ Force serta rasa, aroma, tekstur, dan kenampakan yang mirip dengan unagi shirayaki asal sidat normal (black).
\end{abstract}

Kata kunci: Papain; Shirayaki; Sidat; Tekstur; Unagi

\section{Characterization of Shirayaki Unagi Made from Sidat Fish Soaking by Papain Enzyme}

\begin{abstract}
Unagi Shirayaki is an intermediate product which is further processed into unagi Kabayaki with the addition of a special sauce to produce a processed product with a asoft and tender texture. The obstacle faced in processing Kabayaki Unagi is the emergence of tough eel meat texture from abnormal eel (brown) which is different from normal eel (black) which can result in a decrease in the level of consumer preference. Papain enzyme is used to improving the texture of Unagi Shirayaki. The purposes of this study are to determine the characteristics of Unagi Shirayaki as the result of enzyme application and to determine the concentration and duration of soaking the best papain enzyme to improve the characteristics of Unagi Shirayaki. A total of 3 consentrations of papain enzyme $(0.5,1.0$ and $1.5 \%)$ and 3 periods of soaking $(5,10,15$ minutes) were used in this study. The parameters tested include proximate content (water content, ash content, fat content, protein content), total bacteria, $\mathrm{pH}$, texture and organoleptic. The results showed that the best concentration and duration of soaking of the papain enzyme to improve the characteristics of Unagi Shirayaki was immersion using papain enzyme solution with a concentration of $0.5 \%$ for 15 minutes. The resulting product has a total bacterial colony of $1.04 \times 10^{-3}, \mathrm{pH} 7.0$, a water content of $51.39 \%$, a fat content of $18.24 \%$, a protein content of $26.70 \%$ an ash content of $0.85 \%$, a reducing sugar content of $0.00 \%$, a hardness level of $2,493.11 \mathrm{~g} /$ Force, elasticity 57.85 $\mathrm{g} /$ Force and taste, aroma, texture, and appearance similar to Unagi Shirayaki from normal eels.
\end{abstract}

Keywords: Eel; Papain; Shirayaki;Texture; Unagi

http://ejurnal.ung.ac.id/index.php/jpj/issue/arch 


\section{PENDAHULUAN}

Unagi Kabayaki adalah salah satu produk olahan sidat khas Jepang. Sidat diolah dengan cara dibelah dan dibuang isi perut dan tulang dan dimasak dengan cara dipanggang, dikukus, dan dipanggang (Shirayaki). Shirayaki kemudian dipanggang kembali dan ditambahkan dengan saus manis khas kabayaki, untuk selanjutnya dikemas ke dalam plastik vacuum dan kemudian dibekukan (Widyasari, 2014).

Proses pemasakan Shirayaki dan Kabayaki adalah pelunakan daging secara fisik. Proses pelunakan merupakan proses perubahan struktur serat protein dari yang rigid menjadi amorf sehingga secara fisik dapat dilihat dari kenyal menjadi empuk, dari yang sulit dikunyah menjadi mudah. Namun, saat ini hasil dari pelunakan daging secara fisik masih kurang memberi efek untuk Shirayaki yang berasal dari sidat yang secara fisik berbeda dengan sidat sejenisnya (abnormal). Sidat normal memiliki warna kulit hitam bersih sedangkan sidat abnormal memiliki warna kulit abu kusam. Tekstur Shirayaki berbahan sidat abnormal setelah proses pemanggangan menjadi alot jika dibandingkan dengan sidat normal. Setelah dipanggang Shirayaki seharusnya memiliki tekstur yang lembut dan empuk, serta daging yang menyatu dengan kulit. Sedangkan Shirayaki yang berbahan dasar sidat abnormal memiliki tektur yang alot dan keras serta daging yang terpisah dari kulit. Salah satu teknik untuk mensiasati kekurangan tersebut yaitu dengan pelunakan daging secara kimia.

Pelunakan daging secara kimia dapat dilakukan melalui dua cara yakni secara enzimatis dan non enzimatis. Secara enzimatis menggunakan enzim sedangkan non enzimatis menggunakan asam. Pelunakan menggunakan asam ini sering dilakukan, baik di rumah maupun di restoran, hanya saja dapat mengurangi nilai gizinya karena sebagian protein dapat terdenaturasi atau rusak oleh asam (Silaban $d k k, 2016$ ). Enzim yang dapat digunakan untuk merubah tekstur daging menjadi empuk adalah papain.

Enzim papain merupakan salah satu enzim protease (pengurai protein). Enzim ini mempunyai kemampuan menguraikan ikatan dalam molekul protein sehingga protein terurai menjadi polipeptida dan dipeptida. Pada daging, enzim ini bekerja dengan menguraikan protein daging sehingga daging menjadi empuk. Enzim ini dapat bekerja pada suhu tinggi, sehingga proses pengempukan daging dapat terjadi pada saat daging dimasak (Silaban $d k k, 2016$ ).

Penggunaan enzim papain pada umumnya adalah untuk daging merah seperti daging sapi (Nurhayati dkk, 2010) dan daging unta (Abdel-Naeum dan Mohame, 2016). Papain juga diaplikasikan dalam pembuatan Kecap Ikan (Budiwan, 2011) dan Hidrolisat Protein Ikan (Li $d k k, 2015)$. Namun, sampai saat ini belum ada penelitian mengenai penggunaan enzim yang cocok untuk olahan sidat. Mengingat hal 
tersebut, maka perlu dilakukan penelitian mengenai pengaruh penggunaan enzim papain untuk dapat memperbaiki tekstur dari sidat abnormal setelah proses pemanggangan. Tujuan penelitian ini untuk mengetahui karakteristik Unagi Shirayaki hasil perendaman enzim serta untuk mengetahui konsentrasi dan lama perendaman enzim papain terbaik untuk memperbaiki karakteristik Unagi Shirayaki.

\section{METODE PENELITIAN}

\section{Alat dan Bahan}

Alat yang digunakan antara lain Termometer, Texture Analyzer, pH meter, seperangkat alat analisis (labu destruksi, erlenmeyer, buret, gelas ukur, dan labu kjeldahl, perangkat alat destilasi, perangkat alat ekstraksi soxlet, cawan porselin, tanur pengabuan, kertas saring whatman), timbangan elektrik, oven. Bahan yang digunakan antara lain: Unagi Shirayaki dari sidat normal (black) serta shirayaki dari sidat abnormal (brown) yang disediakan oleh PT. Iroha Sidat Indonesia, Enzim Papain, dan aquades.

\section{Prosedur penelitian}

Metode yang digunakan dalam penelitian ini adalah metode Eksperimental Laboratorium dengan Rancangan Acak Kelompok (Tabel 1). Tahapan percobaan disajikan dalam Gambar 1.
Tabel 1. Rancangan Percobaan

\begin{tabular}{|c|c|c|c|}
\hline $\begin{array}{c}\text { Kode } \\
\text { Perlakuan }\end{array}$ & $\begin{array}{l}\text { Jenis } \\
\text { Sidat }\end{array}$ & $\begin{array}{c}\text { Konsentrasi } \\
\text { Enzim } \\
\text { Papain } \\
(\%)\end{array}$ & $\begin{array}{c}\text { Waktu } \\
\text { Perendaman } \\
\text { (Menit) }\end{array}$ \\
\hline $\begin{array}{l}\text { Kontrol (+) } \\
\text { Kontrol (-) }\end{array}$ & $\begin{array}{l}\text { Black } \\
\text { Brown }\end{array}$ & 0,0 & 0 \\
\hline $\mathrm{A} 1$ & Brown & 0,5 & \\
\hline A2 & Brown & 1,0 & 5 \\
\hline A3 & Brown & 1,5 & \\
\hline A4 & Brown & 0,5 & \\
\hline A5 & Brown & 1,0 & 10 \\
\hline A6 & Brown & 1,5 & \\
\hline A7 & Brown & 0,5 & \\
\hline A8 & Brown & 1,0 & 15 \\
\hline A9 & Brown & 1,5 & \\
\hline
\end{tabular}

\section{Pembuatan dan penggunaan larutan enzim papain}

Larutan enzim papain dengan konsentrasi 0,5, 1,0 dan $1,5 \%$ masing-masing dibuat dengan melarutkan serbuk enzim papain sebanyak 0,5, 1,0 dan $1,5 \mathrm{~g}$ kedalam $100 \mathrm{~mL}$ akuades. Larutan kemudian diaduk menggunakan magnetic stirrer selama 10 menit pada suhu ruang $\left(25^{\circ} \mathrm{C}\right)$.

\section{Perendaman sidat pada larutan enzim papain}

Shirayaki dengan kode brown sebanyak 10 buah dan shirayaki dengan kode black sebanyak 1 buah ditimbang dengan kategori bobot masing-masing berkisar antara 150-200 gr. Shirayaki brown direndam sesuai perlakuan dalam larutan enzim papain dengan perbandingan $100 \mathrm{ml}$ Larutan untuk 1 buah shirayaki. Shirayaki direndam pada wadah plastik berukuran $20 \times 15 \times 5 \mathrm{~cm}^{3}$ dengan lama sesuai dengan perlakuan. Shirayaki kode black) dan Shirayaki (brown) kode tanpa perendaman disisihkan sebagai kontrol positif dan negatif. 


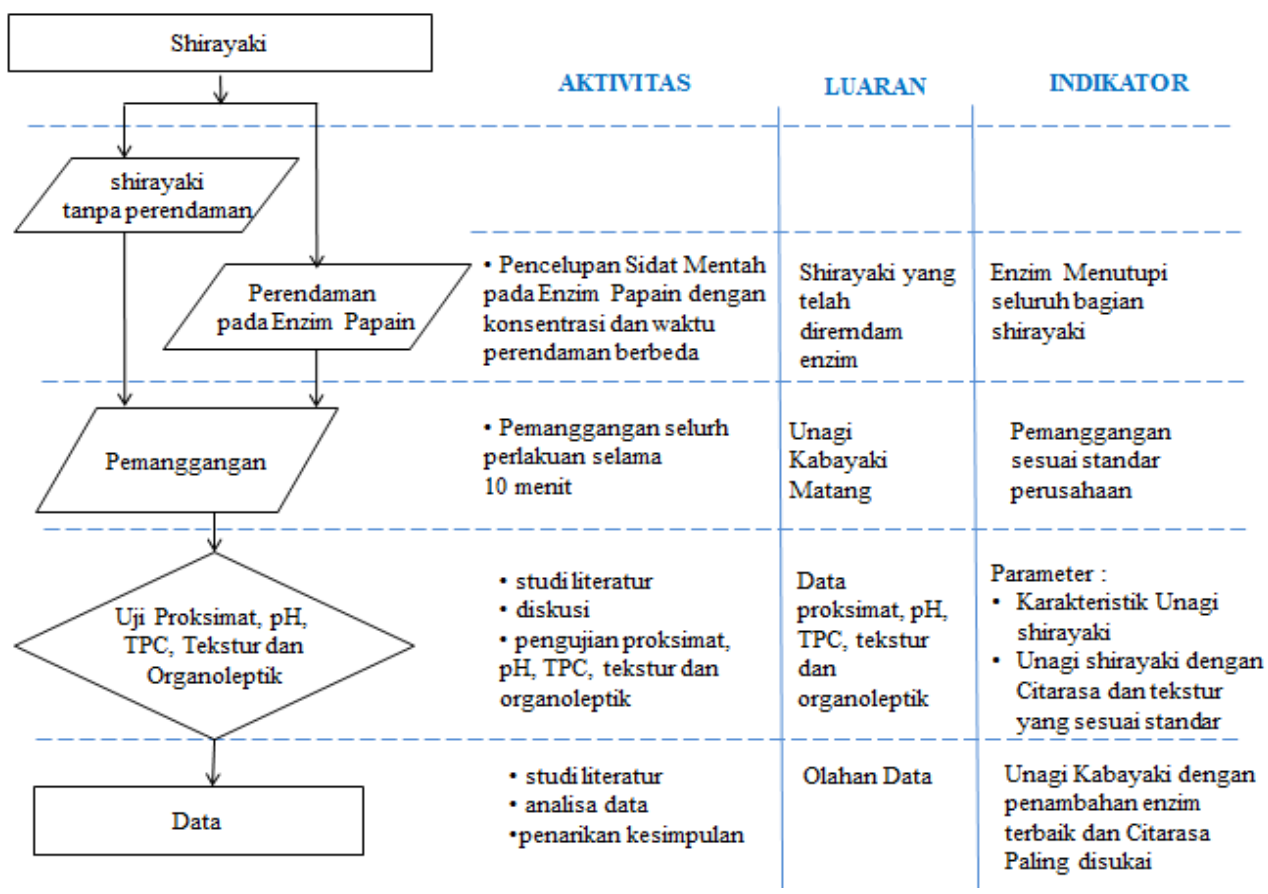

Gambar 1. Tahapan Analisis Unagi Kabayaki

\section{Analisis dan Pengukuran kualitas Shirayaki}

Total bakteri dianalis menggunakan metode total plate count (TPC) (Fardiaz, 1992). Derajat keasaman diukur menggunakan pH meter (Hanna, H198107). Kadar air dan kadar abu sample diukur menggunakan metode gravimetric. Kadar lemak diukur dengan metode soxhlet. Kadar protein diukur dengan metode Kjehdal. Kadar gula reduksi yang diukur dengan metode Luff Schooris. Data hasil uji selanjutnya dianalisis secara deskriptif.

\section{HASIL DAN PEMBAHASAN}

\section{Total bakteri}

Hasil pengujian jumlah bakterimenunjukkan bahwa penambahan enzim papain memberi dampak penghambatan pertumbuhan bakteri (Tabel 2). Semakin tinggi konsentrasi dan lama perendaman enzim maka semakin besar efek penghambatannya.

Produk mengandung bakteri yang berasal dari bahan produk, air dan lingkungan pada saat pembuatannya. Jumlah bakteri pada shirayaki yang direndam pada larutan enzim papain jumlahnya semakin sedikit. Papain yang bersifat bakteriostatik mampu menghambat pertmbuhan bakteri (Ghanbari et al., 2012). 
Tabel 2. Total Koloni Bakteri Unagi Shirayaki yang direndam pada larutan enzim papain

\begin{tabular}{|c|c|c|c|c|c|c|c|}
\hline \multirow{2}{*}{ No. } & \multirow{2}{*}{$\begin{array}{l}\text { Kode } \\
\text { Sample }\end{array}$} & \multirow{2}{*}{ Perlakuan } & \multicolumn{4}{|c|}{ Pengenceran } & \multirow{2}{*}{ Hasil } \\
\hline & & & $10^{-1}$ & $10^{-2}$ & $10^{-3}$ & $10^{-4}$ & \\
\hline 1. & Kontrol (+) & $0,0 \%, 0^{\prime}$ & 188 & 41 & 5 & 0 & $1,88 \times 10^{-3}$ \\
\hline 2. & Kontrol (-) & $0,0 \%, 0^{\prime}$ & 169 & 48 & 6 & 0 & $1,69 \times 10^{-3}$ \\
\hline 3. & $\mathrm{~A} 1$ & $0,5 \%, 5^{\prime}$ & 143 & 32 & 3 & 0 & $1,43 \times 10^{-3}$ \\
\hline 4. & A2 & $0,5 \%, 10^{\prime}$ & 128 & 30 & 3 & 0 & $1,28 \times 10^{-3}$ \\
\hline 5. & A3 & $0,5 \%, 15^{\prime}$ & 104 & 28 & 3 & 0 & $1,04 \times 10^{-3}$ \\
\hline 6. & A4 & $1,0 \%, 5^{\prime}$ & 67 & 18 & 1 & 0 & $6,70 \times 10^{-2}$ \\
\hline 7. & A5 & $1,0 \%, 10^{\prime}$ & 58 & 17 & 0 & 0 & $5,80 \times 10^{-2}$ \\
\hline 8. & A6 & $1,0 \%, 15^{\prime}$ & 54 & 14 & 0 & 0 & $5,40 \times 10^{-2}$ \\
\hline 9. & A7 & $1,5 \%, 5^{\prime}$ & 49 & 10 & 0 & 0 & $4,90 \times 10^{-2}$ \\
\hline 10. & A8 & $1,5 \%, 10^{\prime}$ & 43 & 2 & 0 & 0 & $4,30 \times 10^{-2}$ \\
\hline 11. & A9 & $1,5 \%, 15^{\prime}$ & 32 & 2 & 0 & 0 & $3,20 \times 10^{-2}$ \\
\hline
\end{tabular}

\section{Kadar keasaman (pH)}

Hasil pengujian kadar keasaman $(\mathrm{pH})$ memiliki kecenderungan penurunan seiring dengan peningkatan konsentrasi larutan enzim papain dan lama perendamannya (Tabel 3). Namun, hasil pengujian tidak menunjukkan perbedaan yang signifikan.

Tabel 3. pH Shirayaki yang direndam larutan enzim papain.

\begin{tabular}{cccc}
\hline No. & $\begin{array}{c}\text { Kode } \\
\text { Sample }\end{array}$ & Perlakuan & Hasil \\
\hline 1. & Kontrol $(+)$ & $0,0 \%, 0^{\prime}$ & 7,04 \\
2. & Kontrol $(-)$ & $0,0 \%, 0^{\prime}$ & 7,14 \\
3. & A1 & $0.5 \%, 5^{\prime}$ & 7,15 \\
4. & A2 & $0,5 \%, 1^{\prime}$ & 7,04 \\
5. & A3 & $0,5 \%, 1^{\prime}$ & 7,00 \\
6. & A4 & $1,0 \%, 5^{\prime}$ & 7,08 \\
7. & A5 & $1,0 \%, 1^{\prime}$ & 7,02 \\
8. & A6 & $1,0 \%, 15^{\prime}$ & 7,01 \\
9. & A7 & $1,5 \%, 5^{\prime}$ & 7,02 \\
10. & A8 & $1,5 \%, 0^{\prime}$ & 6,98 \\
11. & A9 & $1,5 \%, 15^{\prime}$ & 6,99 \\
\hline
\end{tabular}

http://ejurnal.ung.ac.id/index.php/jfpj/issue/arch
Kondisi pH yang bervariasi berpengaruh terhadap aktivitas spesifik enzim yang bekerja menguraikan substrat (protein daging). Menurut Silaban dkk (2016) enzim papain bekerja aktif pada rentangan $\mathrm{pH} 5,00-7,00$. Hasil penelitian menunjukkan bahwa $\mathrm{pH}$ dari shirayaki yang direndam dengan larutan enzim papain berkisar antara 6,99-7,04.

\section{Kadar Proksimat}

Hasil uji proksimat menunjukan data yang bervariatif pada setiap perlakuan. Larutan enzim papain yang berbeda konsentrasi dan lama perendaman yang dilakukan memiliki pengaruh terhadap kadar proksimat dari sample. Hasil pengujian proksimat disajikan di Tabel 4.

Kadar lemak pada unagi shirayaki pada seluruh perlakuan lebih rendah dari kontrol. Perlakuan dengan kadar lemak yang paling mendekati dengan kontrol adalah pada perlakuan konsentrasi larutan enzim papain 0,5\% selama 15 menit. Kadar lemak yang lebih rendah 
dibandingkan dengan kontrol bisa disebabkan oleh jenis sidat yang digunakan. Papain kemudian dapat digunakan sebagai antioksidan alami, karena mampu mencegah proses oksidasi pada daging ikan (Li et al., 2015).

Berbanding terbalik dengan kadar lemak, kadar protein pada unagi shirayaki pada seluruh perlakuan lebih tinggi dari kontrol. Kadar protein yang lebih tinggi dibandingkan dengan kontrol disebabkan penggunaan enzim yang diberikan. Perendaman larutan enzim papain memberikan pengaruh yang bervariasi. Enzim papain dengan kadar air yang mendekati nilai kontrol adalah pada perlakuan $1,0 \%, 15^{\prime}, 1,5 \%, 5^{\prime}$ dan $1,5 \%, 0^{\prime}$. Kadar gula reduksi (karbohidrat) hasil pengujian tidak dapat dihitung. Kandungan gula reduksi pada shirayaki sangat rendah, sehingga hasil yang didapat pada semua sampel adalah $0 \%$.

Tabel 4. Kadar Proksimat Unagi Shirayaki yang direndam larutan enzim papain

\begin{tabular}{cccccccc}
\hline No. & $\begin{array}{c}\text { Kode } \\
\text { Sample }\end{array}$ & Perlakuan & $\begin{array}{c}\text { Kadar } \\
\text { Air } \\
(\%)\end{array}$ & $\begin{array}{c}\text { Kadar } \\
\text { Lemak } \\
(\%)\end{array}$ & $\begin{array}{c}\text { Kadar } \\
\text { Abu } \\
(\%)\end{array}$ & $\begin{array}{c}\text { Kadar } \\
\text { Protein } \\
(\%)\end{array}$ & $\begin{array}{c}\text { Kadar Gula } \\
\text { Reduksi } \\
(\%)\end{array}$ \\
\hline 1. & Kontrol (+) & $0,0 \%, 0^{\prime}$ & 50,18 & 19,15 & 1,06 & 27,02 & 0,00 \\
2. & Kontrol (-) & $0,0 \%, 0^{\prime}$ & 51,28 & 18,65 & 1,19 & 26,70 & 0,000 \\
3. & A1 & $0,5 \%, 5^{\prime}$ & 52,11 & 15,59 & 1,13 & 28,31 & 0,00 \\
4. & A2 & $0,5 \%, 1^{\prime}$ & 51,61 & 17,75 & 1,20 & 26,52 & 0,00 \\
5. & A3 & $0,5 \%, 15^{\prime}$ & 51,39 & 18,24 & 0,85 & 26,70 & 0,00 \\
6. & A4 & $1,0 \%, 5^{\prime}$ & 46,81 & 16,59 & 0,98 & 32,74 & 0,00 \\
7. & A5 & $1,0 \%, 10^{\prime}$ & 46,55 & 16,75 & 0,97 & 32,93 & 0,00 \\
8. & A6 & $1,0 \%, 15^{\prime}$ & 47,62 & 16,76 & 1,02 & 31,75 & 0,00 \\
9. & A7 & $1,5 \%, 5^{\prime}$ & 48,74 & 16,62 & 1,01 & 30,80 & 0,00 \\
10. & A8 & $1,5 \%, 10^{\prime}$ & 48,13 & 17,82 & 1,01 & 30,45 & 0,00 \\
11. & A9 & $1,5 \%, 15^{\prime}$ & 48,15 & 17,93 & 1,18 & 30,18 & 0,00 \\
\hline
\end{tabular}

\section{Tekstur (Kuantitatif)}

Pengujian tekstur secara kuantitatif dilakukan dengan melakukan pengujian kekerasan dan kekenyalan unagi shirayaki. Hasil kemudian dibandingkan, unagi shirayaki yang direndam pada larutan enzim papain dengan unagi shirayaki standar yang berasal dari sidat normal (black) sebagai kontrol positif (Tabel 5).
Semakin tinggi nilai kekerasan dan kekenyalan produk maka semakin empuk unagi shirayaki tersebut. Dari data yang didapat maka perlakuan perendaman larutan enzim papain dengan konsentrasi 0,5\% selama 15 menit memiliki nilai kekerasan dan kekenyalan yang paling mendekati dengan kontrol positif. 
Tabel 5. Tekstur Unagi Shirayaki yang direndam pada Larutan Enzim Papain

\begin{tabular}{ccccc}
\multicolumn{4}{c}{ pada Larutan Enzim Papain } \\
\hline No. & $\begin{array}{c}\text { Kode } \\
\text { Sample }\end{array}$ & Perlakuan & $\begin{array}{c}\text { Kekerasan } \\
\text { (g/Force) }\end{array}$ & $\begin{array}{c}\text { Kekenyalan } \\
\text { (g/Force) }\end{array}$ \\
\hline 1. & Kontrol (+) & $0.0 \%, 0^{\prime}$ & 2374,77 & 57,37 \\
2. & Kontrol (-) & $0.0 \%, 0^{\prime}$ & 1392,22 & 53,93 \\
3. & A1 & $0.5 \%, 5^{\prime}$ & 1925,13 & 60,32 \\
4. & A2 & $0.5 \%, 1^{\prime}$ & 2244,80 & 56,14 \\
5. & A3 & $0.5 \%, 15^{\prime}$ & 2493,11 & 57,85 \\
6. & A4 & $1.0 \%, 5^{\prime}$ & 2182,08 & 58,69 \\
7. & A5 & $1.0 \%, 10^{\prime}$ & 2237,96 & 60,72 \\
8. & A6 & $1.0 \%, 15^{\prime}$ & 3134,01 & 59,64 \\
9. & A7 & $1.5 \%, 5^{\prime}$ & 2518,62 & 63,23 \\
10. & A8 & $1.5 \%, 10^{\prime}$ & 3117,38 & 60,26 \\
11. & A9 & $1.5 \%, 15^{\prime}$ & 2226,04 & 62,06 \\
\hline
\end{tabular}

Tabel 6. Hasil Organoleptik Unagi Shirayaki yang direndam pada Larutan Enzim Papain

\begin{tabular}{ccccccc}
\hline No. & $\begin{array}{c}\text { Kode } \\
\text { Sample }\end{array}$ & Perlakuan & Rasa & Aroma & Tekstur & Kenampakan \\
\hline 1. & Kontrol (+) & $0.0 \%, 0^{\prime}$ & 1 & 1 & 1 & 1 \\
2. & Kontrol (-) & $0.0 \%, 0^{\prime}$ & 1 & 1 & 0 & 1 \\
3. & $\mathrm{~A} 1$ & $0.5 \%, 5^{\prime}$ & 1 & 1 & 0 & 1 \\
4. & $\mathrm{~A} 2$ & $0.5 \%, 0^{\prime}$ & 1 & 1 & 0 & 1 \\
5. & $\mathrm{~A} 3$ & $0.5 \%, 5^{\prime}$ & 1 & 1 & 1 & 1 \\
6. & $\mathrm{~A} 4$ & $1.0 \%, 5^{\prime}$ & 1 & 1 & 1 & 1 \\
7. & $\mathrm{~A} 5$ & $1.0 \%, 10^{\prime}$ & 1 & 1 & 1 & 1 \\
8. & $\mathrm{~A} 6$ & $1.0 \%, 15^{\prime}$ & 1 & 1 & 1 & 1 \\
9. & $\mathrm{~A} 7$ & $1.5 \%, 5^{\prime}$ & 1 & 1 & 1 & 1 \\
10. & $\mathrm{~A} 8$ & $1.5 \%, 10^{\prime}$ & 0 & 1 & 0 & 1 \\
11. & $\mathrm{~A} 9$ & $1.5 \%, 15^{\prime}$ & 0 & 1 & 0 & 1 \\
\hline
\end{tabular}

Ket: bobot $1=$ memiliki kesamaan dengan kontrol; bobot $0=$ berbeda dengan kontrol

Perendaman pada enzim papain tidak memberikan pengaruh terhadap aroma dan kenampakan unagi shirayaki, tetapi berpengaruh pada tekstur dan rasa. Hasil pengujian menunjukan bahwa terdapat 5 perlakuan yang memiliki karakteristik organoleptik yang mendekati atau sama dengan kontrol positif.

\section{Tekstur (Kualitatif)}

Unagi shirayaki yang berasal dari sidat abnormal/brown, shirayaki dengan perendaman konsentrasi $0,5 \%$ selama 5 menit dan http://ejurnal.ung.ac.id/index.php/jfpj/issue/arch

\section{Organoleptik}

Pengujian organoleptik pada unagi shirayaki shirayaki yang direndam pada larutan enzim papain dengan unagi shirayaki standar yang berasal dari sidat normal (black) sebagai kontrol positif. Hasil pengujian menunjukan terdapat perbedaan pada tekstur unagi shirayaki yang direndam dibandingkan dengan kontrol. Hasil pengujian disajikan pada Tabel 6 . 


\section{Rasa}

Penambahan enzim papain dengan konsentrasi tertinggi berpengaruh terhadap rasa dari unagi shirayaki, yaitu pada perendaman enzim konsentrasi $1,5 \%$ selama 10 menit dan konsentrasi 1,5\% selama 15 menit. Pada perlakuan tersebut unagi shirayaki meninggalkan rasa pahit. Rasa pahit tersebut berasal dari larutan enzim yang diberikan. Sehingga pada kedua perlakuan tersebut tidak disukai dan menjadi sangat berbeda dibandingkan dengan kontrol.

Papain memberikan pengaruh pada unagi shirayaki asal unagi abnormal (brown). Hasil uji menunjukkan bahwa konsentrasi enzim papain dan lama perendaman memberikan pengaruh yang berbeda. Karakteristik organoleptik dari sidat abnormal (brown) yang mirip dengan sidat normal (black) dapat dipengaruhi oleh kandungan bakteri yang sedikit sehingga mencegah perusakan kenampakan serta tekstur daging yang disebabkan oleh bakteri (Zogul et al., 2005). Enzim papain yang merupakan protein nabati akan meresap kedalam daging unagi sehingga kadar protrein pada unagi shirayaki pun bertambah (Wljayanti dkk, 2015). Kombinasi penggunaan papain dan proses pengolahan menggunakan panas juga dapat memperbaiki tekstur dari daging yang disebabkan oleh perombakan pada otot daging (Barekat dan Soltanizadeh, 2017). Konsentrasi dan lama perendaman enzim papain terbaik untuk memperbaiki karakteristik Unagi Kabayaki adalah larutan enzim papain $0.5 \%$ dan lama perendaman 15 menit. Total koloni bakteri yang aman untuk dikonsumsi, pH netral, kadar air dan kadar lemak dengan nilai yang cukup, serta kadar protein, kadar abu, kadar gula reduksi, kekerasan, kekenyalan serta rasa, aroma, tekstur, dan kenampakan yang mirip dengan kontrol positif yaitu unagi shirayaki asal sidat normal (black).

\section{SIMPULAN}

Konsentrasi dan lama perendaman enzim papain terbaik untuk memperbaiki karakteristik Unagi Kabayaki adalah larutan enzim papain konsentrasi $0.5 \%$ dan lama perendaman 15 menit. Dengan total koloni bakteri sebanyak $1.04 \times 10^{-3}, \mathrm{pH} 7.00$, kadar air sebesar $51.39 \%$, Kadar lemak $18.24 \%$, Kadar protein $26.70 \%$ Kadar abu $0.85 \%$, Kadar Gula Reduksi $0.00 \%$, Kekerasan 2493,11 g/Force, Kekenyalan 57,85 g/Force serta Rasa, Aroma, Tekstur, dan Kenampakan yang mirip dengan Unagi Shirayaki asal sidat normal (black). Analisis lanjutan serta pengujian proksimat terutama kadar air dan kadar lemak dari sidat mentah hingga unagi shirayaki yang telah diproses menjadi unagi kabayaki dirasa perlu untuk dapat dijadikan sebagai data acuan yang dapat digunakan di industri.

\section{UCAPAN TERIMAKASIH}

Penelitian ini dilaksanakan di Laboratorium Pengolahan Hasil Perikanan Fakultas Perikanan Universitas Padjadjaran (Sumedang, Jawa Barat, 
Indonesia) dan dibiayai oleh PT Iroha Sidat Indonesia JAPFA, (Banyuwangi, Jawa Timur, Indonesia).

\section{DAFTAR PUSTAKA}

Abdel-naeem, H.H.S., Mohamed, H.M.H. 2016. Improving the physico-chemical and sensory characteristics of camel meat burger patties using ginger extract and papain. Meat Science. 118: 52-60.

Barekat, S. 2017. Improvement of meat tenderness by simultaneous application of high-intensity ultrasonic radiation and papain treatment. Innovative Food Science and Emerging Technologies. 39: 223-229.

Budiwan, D.N. 2011. Aplikasi papain pada fermentasi kecap ikan. [Skripsi]. Fakultas Teknologi Pertanian. Universitas Katolik Soegijapranata. Semarang.

Fardiaz, S. 1992. Mikrobiologi Pangan I. Gramedia. Jakarta..

Ghanbari, R., Ebrahimpour, A., Abdul-hamid, A., Ismail, A. 2012. Actinopyga lecanora Hydrolysates as Natural Antibacterial Agents. International Journal of Molecular Science. 13: 16796-16811.
Li, X., Luo, Y., You, J., Shen, H. 2015. Stability of papain-treated grass carp (Ctenopharyngodon idellus) protein hydrolysate during food processing and its ability to inhibit lipid oxidation in frozen fish mince. Journal of Food Science and Technology. 52: 542-548.

Silaban, R., Panggabean, F.T.M., Rahmadani, Soripada, T.A. 2016. Studi pemanfaatan enzim papain getah buah pepaya untuk melunakkan daging. Diakses dari : http://digilib.unimed.ac.id/id/eprint/821

O" zogul, Y., O" zyurt, G., O" zogul, F., Kuley, E., Polat, A. 2005. Freshness assessment of European eel (Anguilla anguilla) by sensory, chemical and microbiological methods. Food Chemistry. 92: 745-751.

Widyasari, A.H.E., Kusharto, C.M., Wiryawan, B. 2014. Nutritive Value and Fatty Acids Profi le of Fresh Indonesian Eel (Anguilla bicolor) and Kabayaki. Jurnal Sains Kesihatan Malaysia. 12(1): 41-46.

Wijayanti, I., Romadhon, Rianingsih. 2015. Pengaruh konsentrasi enzim papain terhadap kadar proksimat dan nilai rendemen hidrolisat protein ikan bandeng (Chanos chanos Forsskal). Pena Akuatika. 12(1): 13-23. 